\title{
Drifting into unconsciousness: Jason Zirganos and the mystery of undetected hypothermia
}

\author{
Mike Tipton
}

Swimming authorities must enforce minimum temperature rules in open water swimming because some open water swimmers-particularly those who are well acclimatised to cold-are unable to judge how cold they are. This potential problem was confirmed in the study of Saycell et al in this issue of British Journal of Sports Medicine. ${ }^{1}$

Cold habituation from repeated exposure to cold water can produce a 'hypothermic' adaptation to cold in which the acclimated individuals lose their perceptual and physiological responses to cooling. They do not shiver as much and paradoxically feel more comfortable as their deep body temperature falls. This was clearly demonstrated in the classic studies of Channel swimmers published in 1955 by Pugh and Edholm. ${ }^{2}$ Pugh's investigations of the greatest open water swimmer of his generation, Jason Zirganos (figure 1), showed that, during resting immersions in cold water, Zirganos' deep body temperature fell more quickly than it should have for a man of his build and subcutaneous fat thickness. The swimmer was unaware of this cooling as he sat in $16^{\circ} \mathrm{C}$ water, comfortable and reading his newspaper. At the same time Pugh, a tall, thin man, unacclimatised to cold, was in an adjacent immersion tank cooling at about the same rate but desperately uncomfortable and almost tetanic with shivering.

The lack of perceptual insight into their thermal state means it is possible for open water swimmers to swim to unconsciousness. This occurred when swimmers attempted to cross the Cook Straight in New Zealand (Phil Rush, three-way Channel swimmer, personal communication to M J Tipton, 2009). It is certainly theoretically possible;

Correspondence to Professor Mike Tipton, Sport and Exercise Science, University of Portsmouth, Portsmouth P01 2UP, UK; michael.tipton@port.ac.uk unconsciousness occurs, on average, at a deep body temperature of $30^{\circ} \mathrm{C}-33^{\circ} \mathrm{C}$, whereas muscle function is maintained down to a temperature of about $27^{\circ} \mathrm{C}$. Swimming hard with sufficient thermal mixing between the (cold) exercising limbs and the deep body tissues lowers body temperature rather uniformly, and this may result in unconsciousness before swim failure. Normally, this does not occur as the steep gradient between the water, superficial tissues (exercising limbs) and deep tissues ensures that neuromuscular incapacitation and swim failure occur before profound hypothermia.

I return to Jason Zirganos and a final tragic tale founded on the consequences of his inability to perceive deep body cooling. In 1953, he swam in the Bosphorus $\left(8^{\circ} \mathrm{C}\right)$ for 4 hours; he was removed from the water semiconscious regaining full consciousness 3 hours later. As he was unaware of hypothermia and did not feel particularly cold, it was assumed that he had been poisoned. A year later, at the age of 46 years, Zirganos attempted to swim the 22-mile North Channel of the Irish Sea $\left(9.4^{\circ} \mathrm{C}-11.7^{\circ} \mathrm{C}\right)$. After 6 hours,

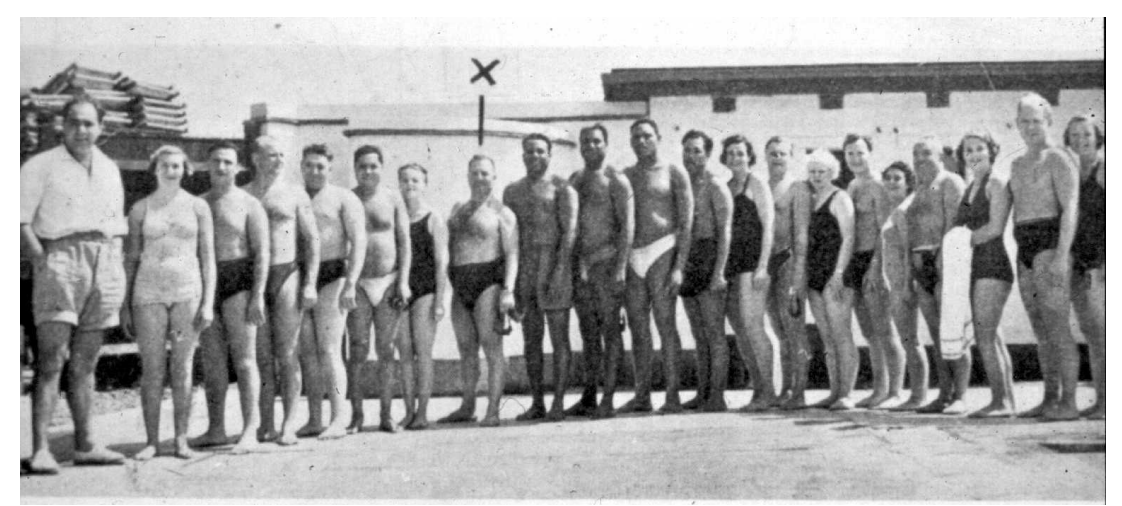

Figure 1 Competitors in cross-Channel race, 1951. Jason Zirganos marked by cross. (Reproduced by kind permission of the Daily Mail.) and only three miles from the Scottish Coast, Zirganos became unconscious and blue; he did not feel 'cold' prior to this. He was hauled from the water, and a doctor, using a pen knife, exposed Zirganos's heart to reveal ventricular fibrillation. Direct heart massage having failed, Jason Zirganos was pronounced dead at the scene (L G 'Griff' Pugh, personal communication to M J Tipton, 1982).

Funding The authors have not declared a specific grant for this research from any funding agency in the public, commercial or not-for-profit sectors.

Competing interests None declared.

Patient consent for publication Not required.

Provenance and peer review Not commissioned; externally peer reviewed.

(C) Author(s) (or their employer(s)) 2019. No commercial re-use. See rights and permissions. Published by BMJ.

A) Check for updates

To cite Tipton M. Br J Sports Med 2019;53:1047.

Accepted 3 February 2019

Published Online First 1 March 2019

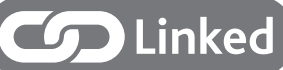

http://dx.doi.org/10.1136/bjsports-2018-099978

Br J Sports Med 2019;53:1047.

doi:10.1136/bjsports-2019-100646

\section{REFERENCES}

1 Saycell J, Lomax M, Massey $H$, et al. How cold is too cold? Establishing the lower water temperature limits for marathon swim racing. British Journal of Sports Medicine 2019:53:1078-84

2 Pugh LG, Edholm OG. The physiology of channel swimmers. Lancet 1955;269:761-8. 